\title{
From Collapsed Coal Mines to Floating Solar Farms, Why China's New Power \\ Stations Matter
}

Hamid M. Pouran

Lecturer in environmental technology and Senior Member IEEEE

The University of Wolverhampton Wulfruna St, Wolverhampton, UK

e-mail: hamidpouran@gmail.com

\begin{abstract}
Inauguration of the world's largest floating solar power plant on a collapsed coal mine exemplifies China's commitment to transition to a low carbon economy. This $70 \mathrm{MW}$ project covers more than 63 hectares of the flooded area and can provide electricity for 21000 homes. It also demonstrates China's ambition to amend its fragile environmental status namely air pollution, which claims 1.6 million lives every year. Soon after the completion, many countries expressed interest in building similar power stations, and within few months some companies released innovative products tailored specifically for improving the efficiency of floating solar power plants. China has a unique capacity to implement new ideas, scale them up and commercialise efficiently and now its self-declared war on pollution in 2014 seems to be reshaping the world energy landscape. China's plan to build 1 GW floating solar farms on abandoned coal mines present a stark contrast to the current environmental policies of the government of the United States. The innovative thinking behind these projects suggests that not only this country is taking the lead in renewable energies, but it is moving beyond speed, efficiency and mass production, and becoming a hub for innovation in green energy technologies.
\end{abstract}

Keywords: Floating Solar Farms, China Energy Policy, Innovation in Solar Energy, Water 


\section{The world's largest floating solar farm}

Huainan is a city of Anhui Province in the eastern region of China and is known for its coal industry. This city has recently attracted the world's attention by opening a new chapter in China's transition to a low carbon economy. In 2017, the biggest floating solar power plant in the world was inaugurated in the vicinity of Huainan, on a flooded area once used for coal mining. The project belongs to China Energy Conservation and Environmental Protection Group $(C E C E P)^{1}$, a state-owned energy conglomerate and a renewable energy project developer.

The government has supported this project aiming to mitigate the damages that overexploitation of coal mines has done to this region. The total surface of the flooded area is 148.4 hectares. This $70 \mathrm{MW}$ project is comprised of almost 194700 solar panels and 52000 float parts, to keep the islands on the water. The power plant is made of 13 float islands, and the capacity of the largest one is approximately $8.5 \mathrm{MW}$. Figure 1 shows the aerial view of the construction of the world's largest floating solar power plant(Credit Google Earth Pro, 2018) ${ }^{2}$ and Figure 2 provides some technical information about the lake and plastic floats used in this project ${ }^{3}$. The total surface of the floating power plant is 63.6 hectares. The solar islands are anchored to the silty clay soil of the bottom of the lake, which has the maximum depth of 14.0 meter. To tolerate water level variations in different seasons, that is less than 4.0 meter, and withstand hydrodynamic impacts of external factors, e.g. wind and rain, the float parts are stabilised using helical anchors. 

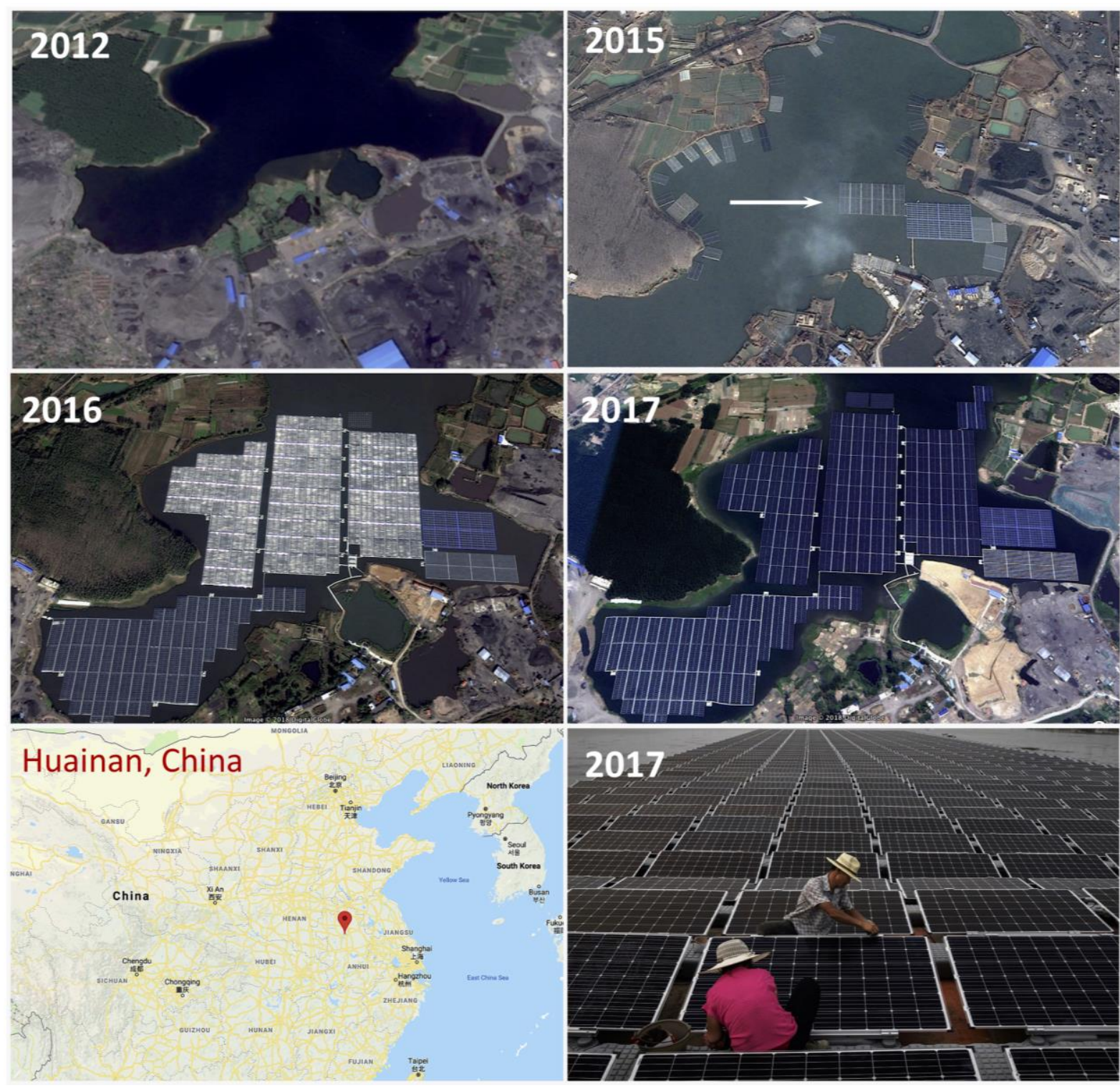

Figure 1. Shows changes to the flooded coal mine subsidence area before and after installation of the floating solar farms (Credit Google Earth Pro, 2018 and Getty images). 


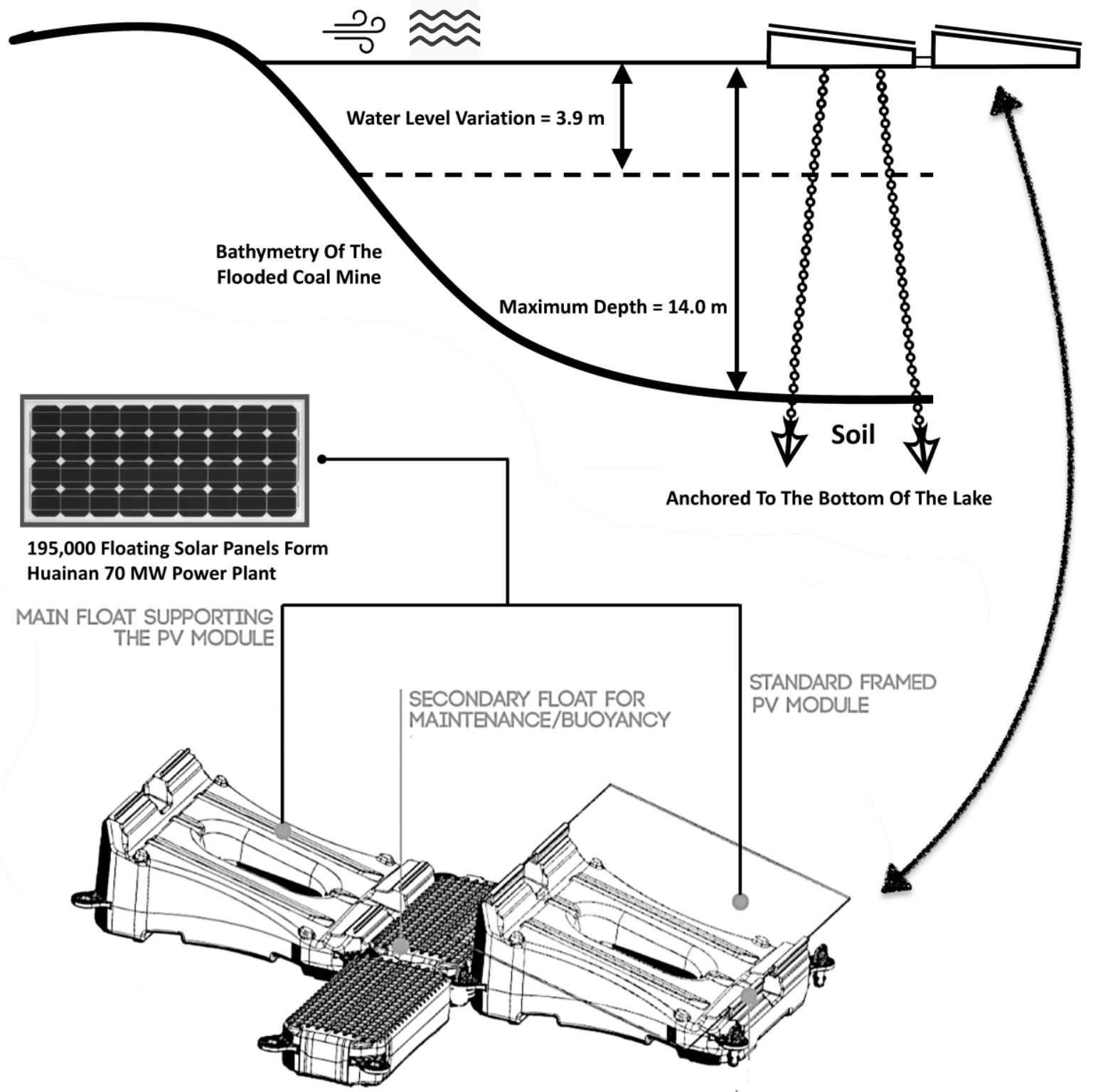

Figure 2. Schematic representation of the installed floating solar power plant on the flooded coal mine in Anhui Province. As seen the float parts need to be flexible yet stable enough to resist water level variations and environmental hydrodynamic impacts. The Figure also illustrates the structure of float part, that keep the solar panels in place. About 52000 of them have been used in the $70 \mathrm{MW}$ floating solar farm ${ }^{4}$. 
The costs of building floating solar power plants are higher than their ground-mounted peers. Several factors influence financial requirements of the projects, which include the location of the water reservoir and the logistics, characteristics of the water body for example; depth, water level variations, soil/bedrock and the type of floats used to support the PV modules. Anchoring or stabilizing the floating power plants, in a way that is compatible with the dynamic nature of the reservoir yet provide long-term reliability constitutes a notable part of the expenses. For the Anhui project in China, which is a shallow water body the total anchoring costs were around 10 USD/kW. For this large-scale floating power plant, the local manufacturing facilities and labor force were used, and the anchors were installed from 4 to $15 \mathrm{~m}$ underwater. In Japan the anchoring price is substantially higher and the aim is to reach $30 \mathrm{USD} / \mathrm{kW}$ or less. The up to date estimate of the floating solar farms costs based on the technology used in Anhui spans from 0.85-1.20 USD/Wp. This is based on the assumption that the float parts are manufactured locally and the logistic impacts for this large plastic parts are reduced to minimum. For example a $1 \mathrm{MW}$ sets of the main and supporting floats needs 25 standard truck loads ${ }^{5}$.

Existing infrastructures, e.g. grid-connection requirements would reduce the costs of building floating solar farms, and in case of flooded coal mines, there are potential cobenefits as very often coal-power plants have been built close to the mines; thus electricity transport infrastructure is there. Coal-burning power plants often have carbon footprints close to 1000 tonnes $\mathrm{CO}_{2} \mathrm{e} / \mathrm{GWh}$, which is the largest compared to other electricity generation systems, and substantially higher than photovoltaic solar ${ }^{6}$. In 2016 China's National Energy Administration (NEA) announced its plan for building $1 \mathrm{GW}$ floating solar stations on the collapsed coal mines ${ }^{7,8}$ (including the Huainan's project). 
The NEA has expressed its support for building innovative green energy infrastructures to improve environmental quality in the coal-rich eastern province of Anhui, where overexploited coal mines have created vast reservoirs ${ }^{4}$. The $70 \mathrm{MW}$ project can provide electricity for more than 21000 homes $^{4}$, a number which would be significantly reduced in the next two decades as the Chinese household energy consumption is expected to double by $2040^{9}$. Shifting from coal mines to floating solar farms is much more than just embracing sustainability, it helps China to mitigate its environmental problems particularly air pollution, which is one the worst in the world and kills hundreds of thousands of people every year ${ }^{10}$

\section{From collapsed coal mines to floating solar farms}

In 2014 Li Keqiang, Chinese Premier, announced China's war on pollution: "we will resolutely declare war against pollution as we declared war against poverty." ${ }^{11}$ In the past four decades, China has prioritised economic growth over the environment, which has made this country the worlds' biggest carbon emitter. A policy that has manifested itself in degraded air quality, soil and water pollution across China as well as emerge of the infamous cancer village ${ }^{12-15}$ The air pollution is so severe that approximately $17 \%$ of all deaths in China or 1.6 million deaths per year are attributed to $\mathrm{it}^{10}$. Figure 3 , shows air pollution across China on a winter day in $2018^{10,16}$. As seen the air quality and the concentration of fine particulate matters (PM 2.5) is unhealthy for most parts of China. It even reaches very unhealthy, and hazardous levels in massive regions over the northeast. 


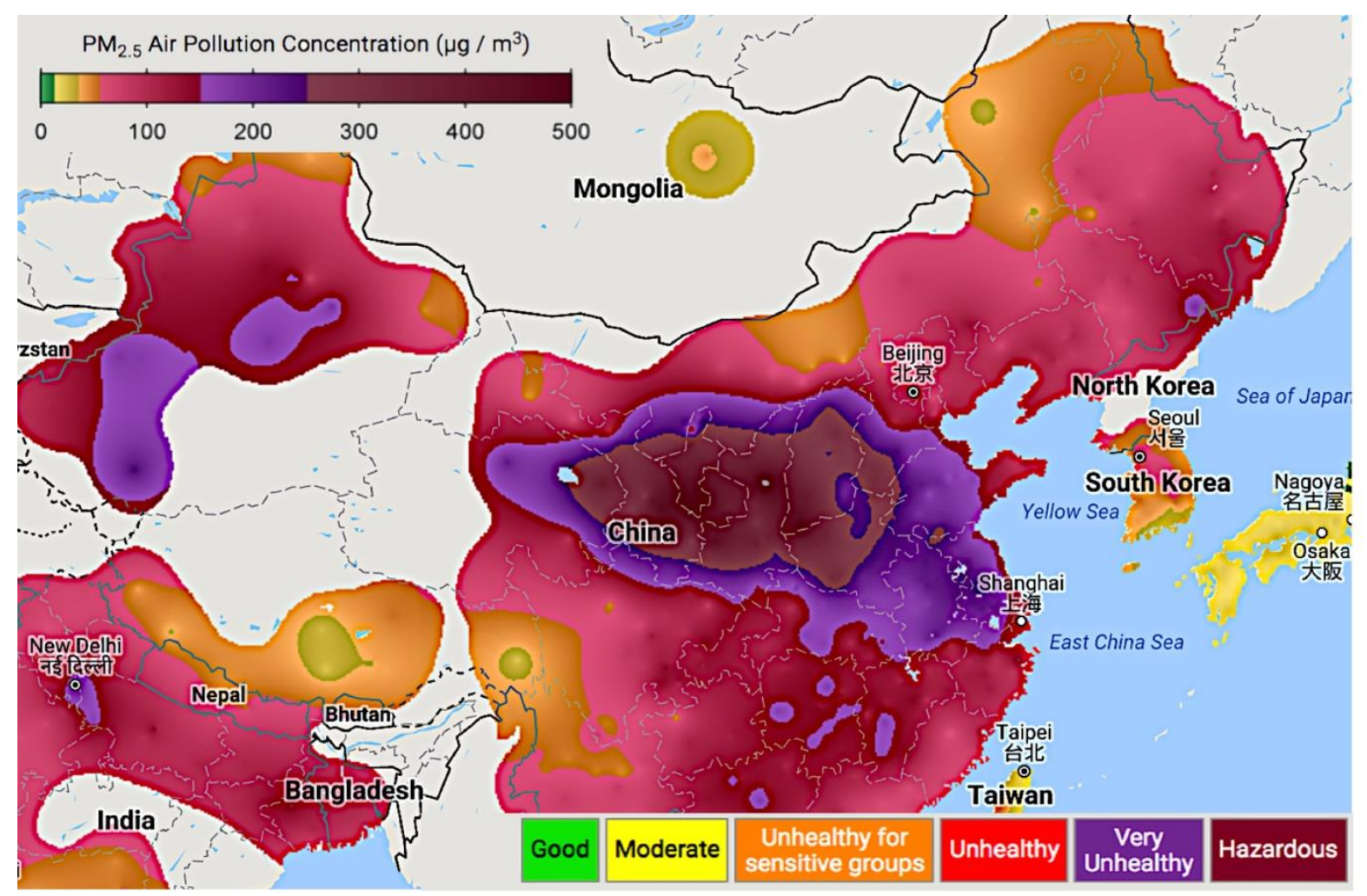

Figure 3. PM 2.5 Concentration Estimate $(\mu \mathrm{g} / \mathrm{m} 3)$ as of February $10^{\text {th } 10,16}$.

Half of the world's annual coal consumption is by China ${ }^{9}$. Such reliance on coal can be partly attributed to the vast coal reserves in China, that is estimated to be the third in the world (after US and Russia) ${ }^{17}$. Figure 4 shows shares of the coal and solar PV in China's energy portfolio from 2000 to 2040 based on its recent energy policies (fighting air pollution and using more renewables). As seen in this Figure, in 2000 approximately $70 \%$ of China's energy was provided by coal, and solar PV had a negligible share. These numbers were around $58 \%$ and $5 \%$ for 2016 and are projected to meet $33 \%$ and $22 \%$ for $2040^{9,18,19}$. This information is based on the announced China's energy and environmental policies aiming to diversify its energy mix while maintaining the economic growth as described by International Energy Agency (IEA $)^{9}$. We see a sharp increase in solar PV share, which is expected to continue in the next two decades, while the coal growth rate is anticipated to remain very slow from 2020. It's worth pointing out that the total electricity generation in China would continue to 
grow. Compared to 2000, the power produced in China has increased five folds in 2016, and expected to reach ten folds by 2040 (more than $3300 \mathrm{GW}$ installed capacity).

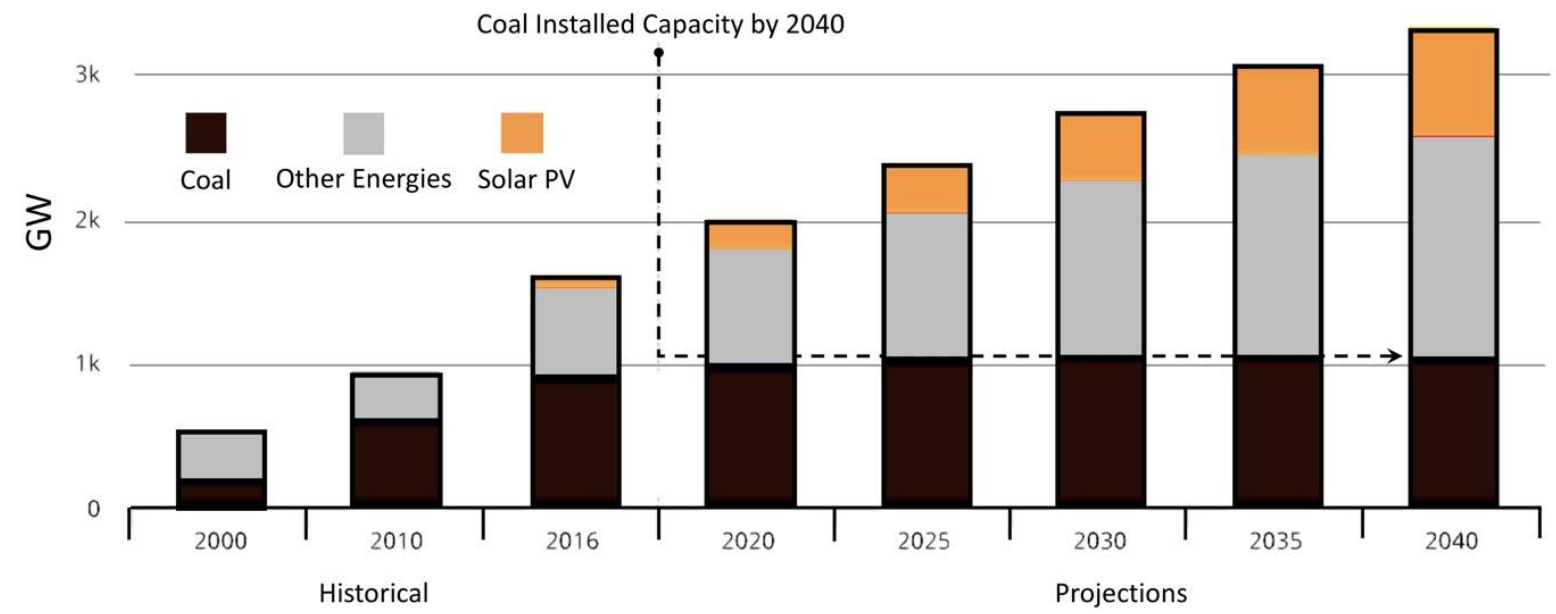

Figure 4. Installed capacity by technology in China in the new environmental policies scenario ${ }^{9}$.

For decades burning coal has supported China's extraordinary economic success, however, this reliable source of energy comes with tremendous health and environmental costs. The release of particulate matter, toxic trace elements and organic chemicals from incomplete combustion of coal cause severe health impacts including lung cancer ${ }^{20}$. Its role in releasing heat-trapping gases into the atmosphere and contributing to climate change is also wellstudied, a global challenge that if not mitigated can drastically disrupt human lives and different ecosystems ${ }^{21}$.

Abandoned coal mines, especially those that are overexploited are predisposed to the collapse of their roofs, which cause the ground above to sink or subside. These collapsed mines are often flooded. The lack of maintenance and closing down of the engineered 
dewatering and drainage systems allow surface and groundwater to accumulate in places of the subsided lands. These types of lakes are good locations to deploy large-scale floating solar power plants and ideal candidates for the China's government to showcase its war on pollution through deploying innovative technologies for improving environmental quality.

In 2015, a year after China's declared war on pollution, the government formally started to implement its revised Environmental Protection Law (EPL), hoping to sustain its economic growth through a different narrative, relying on cleaner energy mix ${ }^{22}$, an ambitious aim, which supports projects like the proposed $1 \mathrm{GW}$ floating solar farms on the flooded coal mines. The new EPL provides the right tool for this war. Nevertheless, it would be only effective if it is implemented and not compromised by political necessities ${ }^{14}$. China's major cities showed improved air quality in 2017 compared to 2015 and 2016, which is attributed to implementing the new environmental regulations ${ }^{23,24}$. Evaluations suggest that while the impacts of the current policies are tangible, they are not consistent and vary for different types of pollutants, e.g. traffic and industrial emissions ${ }^{24,25}$. These new laws are as strong as the political will behind them, if they are maintained their consequences are no less significant for other countries than China's earlier decades of energy-intensive economic growth $^{12}$.

\section{Scaling up innovative transition to a low carbon economy}

Abandoned coal mines flooded with inky water that can contain all kinds of pollutants, often remain unused. In all countries, particularly in China that burning coal still forms its backbone of power generation, the coal mines are reminders of environmental pollution 
and coal miners that have to risk their health. However, the world's largest floating solar power plant in Anhui's province is a game changer. It is installed on the areas that were otherwise unused, all floats for the platforms were produced locally to minimise the carbon footprint, promote employment and cut the logistics costs. The floats can be easily recycled and reused again.

Also, the cooling effect of water reduce the temperature of the PV panels, which prevents overheating and improves efficiency ${ }^{3,4}$ Many countries might be interested in this technology because the appropriate lands for ground-mounted solar farms are too expensive, but there are others in the world that are keen to use floating solar farms for an entirely different reason, preventing water evaporation. In places like the Middle East and North Africa, water scarcity is a severe problem. One of the expected climate change impacts for these regions is prolonged droughts and heat waves, which accelerates evaporation from open water reservoirs. Covering the water surface with floating solar farms allows these countries to incorporate more renewables into their energy mix, reduce their greenhouse gases emissions and decrease water evaporation. That enables them to tackle water scarcity (that is a national challenge for many countries) and also have more efficient solar farms because of lower risks of overheating. United Arab Emirates (UAE) is one of these countries that want to benefit from this innovative approach, promoted by China, to tackle some of its environmental challenges ${ }^{26}$.

Reducing water evaporation, which is one of the compelling features of the floating power plants in the arid regions, is directly affected by design, e.g. shape and size of the floats that support the PV modules and island. Potentially the floating power plants can reduce water evaporation by up to $80 \%$ from the covered surfaces ${ }^{27}$. The company behind the Anhui 
floating solar technology ${ }^{27}$ has provided this estimate based on the Penman equation and its derivatives $^{28,29}$ that calculate evaporation from open water surfaces. Further field experiments using direct measurements techniques would help to gain a better understanding of the impacts of floating solar power plants on the water evaporation which is affected by different variables including; wind, temperature, vapor pressure and the surface $\operatorname{area}^{29}$.

It's worth mentioning that about five years ago the first megawatt-scale, $1.1 \mathrm{MW}$, floating power plant in the world was built on a rainwater retention pond in Okegawa city in Japan $^{30}$. In 2016 Europe's largest floating solar farm was completed. It is on the surface of the Queen Elizabeth II reservoir outside London and connected into the Thames Water's private network ${ }^{31}$. Ironically both Okegawa and London reservoir projects use similar floating PV solar technology to China's on the flooded coal mines, nevertheless none of them attracted even remotely comparable attention ${ }^{32}$ and sparked conversation among public and professionals. Only within a few months after inauguration of the $70 \mathrm{MW}$ floating solar power plants in China, many countries from the Middle East to the US, expressed their interests in using such technology. For example the city of Los Angeles has announced considering an $11 \mathrm{MW}$ floating solar farm on a local reservoir to power more than 3000 homes and reduce water evaporation ${ }^{33}$.

Table 1 shows, features of three major floating solar power plants installed in Japan, the UK and China. As seen in this Table, the nature of the water reservoirs are different but they all use the same technology. Table 2 provides information on completed and ongoing floating solar farm projects across the world based on the technology that was mentioned above (Table 1). This is not an exhaustive list and the data has been provided by the company that 
owns that technology rights ${ }^{27}$. The ongoing projects listed here are beyond the expression of interests and now approaching their final steps. Figure 5, is an example that shows the locations of completed and ongoing floating solar farms in Japan and rest of the East Asia. It is an indication of growing interests in such technology and its distribution across different countries $^{34}$.

\begin{tabular}{|c|c|c|c|}
\hline $\begin{array}{l}\text { Name of the Floating } \\
\text { Solar Power Plant }\end{array}$ & Okegawa & $\begin{array}{l}\text { Queen Elizabeth II } \\
\text { Reservoir }\end{array}$ & Anhui CECEP \\
\hline Country & Japan & UK & China \\
\hline Location & Okegawa & Near London & Huainan \\
\hline Capacity & $1,180 \mathrm{~kW}$ & $6,338 \mathrm{~kW}$ & $70,005 \mathrm{~kW}$ \\
\hline Completion Date & 2013 & 2016 & $2018^{*}$ \\
\hline Reservoir Type & $\begin{array}{l}\text { Rainwater retention } \\
\text { reservoir }\end{array}$ & Drinking water reservoir & $\begin{array}{l}\text { Mine lake/flooded coal } \\
\text { mine }\end{array}$ \\
\hline Maximum Depth & $6.0 \mathrm{~m}$ & $18.4 \mathrm{~m}$ & $14.0 \mathrm{~m}$ \\
\hline Water Level Variation & $6.0 \mathrm{~m}$ & $18.4 \mathrm{~m}$ & $3.9 \mathrm{~m}$ \\
\hline Water Surface & 3.1 ha & $128 \mathrm{ha}$ & 148.4 ha \\
\hline Floating Solar Surface & $1.16 \mathrm{ha}$ & $5.95 \mathrm{ha}$ & 63.58 ha \\
\hline Coverage Ratio & $38 \%$ & $5 \%$ & $43 \%$ \\
\hline
\end{tabular}

Table 1. Features of three major floating solar farms installed on different type of reservoirs in Japan, the UK and China ${ }^{27}$. Ciel et Terre International. Floating Solar Technology documentation / Ciel \&amp; Terre https://www.ciel-et-terre.net/downloads/ * The Anhui CECEP project grid-connection was finalised in 2018. 


\begin{tabular}{lll}
\hline Location of the Floating Solar Power Plants & Capacity & Completion Date \\
\hline Japan (completed projects) & $90 \mathrm{MW}$ & $2013-2018$ \\
Japan (ongoing projects) & $40 \mathrm{MW}$ & $2018-2019$ \\
\hline Europe (completed projects) & $12 \mathrm{MW}$ & $2014-2018$ \\
Europe (ongoing projects) & $2 \mathrm{MW}$ & 2018 \\
\hline North America (completed projects) & $47 \mathrm{~kW}$ & $2016-2017$ \\
North America (ongoing projects) & $8 \mathrm{MW}$ & 2018 \\
\hline Latin America (completed projects) & $430 \mathrm{~kW}$ & $2017-2018$ \\
Latin America (ongoing projects) & $10 \mathrm{MW}$ & 2018 \\
\hline Asia \& Oceania (completed projects) & $100 \mathrm{MW}$ & $2014-2018$ \\
Asia \& Oceania (ongoing projects) & $55 \mathrm{MW}$ & 2018 \\
\hline
\end{tabular}

Table 2. Completed and ongoing floating solar farm projects based on the technology used for Anhui CECEP floating solar project ${ }^{27}$. Ciel et Terre International. Floating Solar Technology documentation / Ciel \&amp; Terre https://www.ciel-et-terre.net/downloads/
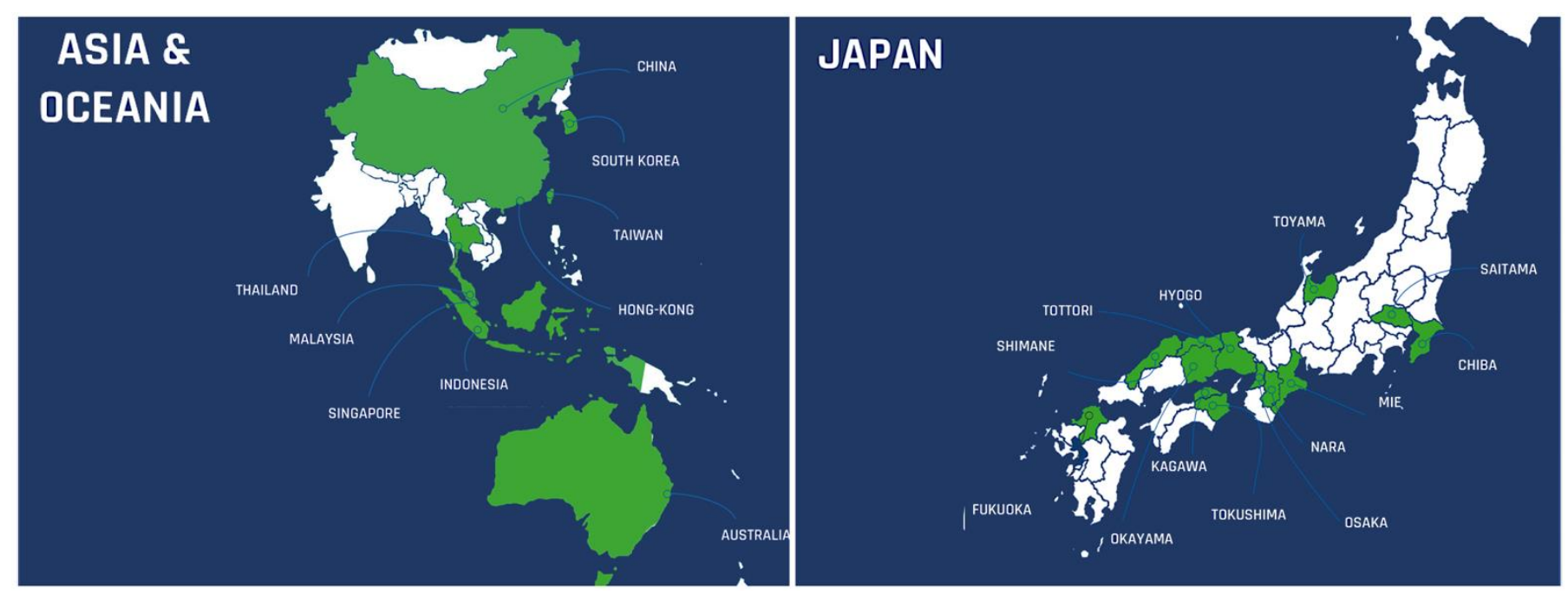

Figure 5. An example of the completed and ongoing floating solar farm projects in Japan and the rest of East Asia, which shows a growing interest in this technology. 
The Okegawa, Queen Elizabeth II reservoir and Anhui CECEP projects represent the versatility and potential applications of floating solar farms. They are installed on the rainwater retention reservoir, drinking water reservoir and mine lakes respectively. Not only these floating solar farms are compatible with the safety requirements of a drinking water reservoir $^{27}$, but they could also be used for seasonal ponds. This type of floating solar farms can be reliably deployed on the deep reservoirs too, for instance, those behind hydroelectric dams. Alto Rabagao $218 \mathrm{kWp}$ floating power plant installed on a dam reservoir with the depth of $90 \mathrm{~m}$ and water level variation of $30 \mathrm{~m}$ is a prime example and was completed in late $2016^{34,35}$.

There is an excellent potential for the floating solar farms, as virtually they could be installed on all different types of water bodies, including open waters. An interesting example is a recent expression of interest to have an offshore prototype off the coast of the Hague in the Netherland ${ }^{36}$. It's fair to say that the commercial viability of the floating solar power plants is a more influential factor than technological barriers in such projects.

China's new power plants showcase this country's efficient approach to managing projects from ideas to launch, and capability to scale up new technological concepts. The scales of implementing innovative green technologies in China creates global visibility and moves international markets. It also helps securing additional funds and financial supports for similar projects across the globe. Moreover, different companies with strong research and 
development expertise start working on these new commercialised concepts to improve them. For instance recently some companies have started to address the shortcomings of the floating solar plants. They want to reduce the considerably high costs of building these plants (compared to land-mounted solar farms) and design reliably efficient waterproof PV panels and cables that withstand years of constant contact with water and harsh environmental conditions.

With this in mind, it's no surprise to hear that South Korea wants to build an even more massive floating solar farm (an $80 \mathrm{MW}$ project) but with a key difference, it would be rotating like a conventional single-axis tracking system and generate up to further $20 \%$ electricity $^{37}$. Also LG Electronics has designed PV panels customised for floating solar power plants, tailored to minimise the corrosion of the module when using over water, with stronger wet-proof property and lead-free ribbon to prevent water pollution ${ }^{38}$. This company has announced its intention to be a key player for the floating solar market that is expected to grow over $2.5 \mathrm{GW}$ by 2024 . The timeline of announcing this product, a few months after Anhui's floating solar plants, suggests it has created global anticipation and set the sail for future projects. A trend that is not new in the green energy market. China's ambitious solar developments has already led to the increased global capacity for producing PV panels and plummeting the solar cells costs. The latest example of these power plants is Longyangxia Dam Solar Park with 4 million solar panels and capacity of 850 megawatts of clean energy, enough to power 200,000 Chinese homes $^{39}$.

The above examples show why China's war on pollution has impacts beyond its borders that can be felt across the world. The revised environmental policies, which are embodied in 
projects like Anhui's floating solar plants, present a stark contrast to the current environmental policies of the government of the United States. The innovative thinking that we see for reusing an abandoned coal mine to generate clean energy and the global wave that it has created can be extended to other green technologies like electric vehicles. China's embracing sustainability at the same time that the U.S. has announced its intention to exit the Paris agreement can pave the road for this country to take the leadership role in the clean energy technologies. Over forty years ago the United States established Solar Energy Research Institute, which became National Renewable Energy Laboratory in $1991^{40}$. Since then despite the American scientists' unique contributions to advancing solar energy, it remained peripheral until China decided to build solar power plants and change its course from fossil fuels to renewables. So far China's speed, mass production and efficiency have shaped the direction of the clean energies, nevertheless, in the emerging absence of the U.S leadership, soon this country may also become a global hub for innovation in clean technologies.

\section{Conclusions}

Since its self-declared war on pollution in 2014 , China has taken bold steps to add more renewables and amend its fragile environmental conditions. The largest floating solar farm in the world installed on a flooded collapsed coal mine is the latest example. Since completion of this project, other countries have expressed their interest in having largescale floating solar farms, and many companies have come up with new products specifically designed to improve this technology. The impacts of China's intention to embrace sustainability on the global market is no less than the effects of its rapid economic growth in the recent decades. China's ability to efficiently move from ideas to products and 
commercialise them in large scales has put it in a unique position to lead the renewable energy market, especially now that the U.S. government seems to relinquish its leadership role. The current floating solar projects on flooded coal mines in Anhui Province, which is intended to reach $1 \mathrm{GW}$, indicates that China is building momentum to move beyond efficient mass production and even become a hub for innovation in the energy industry.

\section{Acknowledgements}

I'd like to thank Ciel et Terre International for providing details of their past and ongoing floating solar farm projects including Anhui CECEP.

\section{References}

(1) China Energy Conservation And Environmental Protection Group \&gt; Home http://www.cecep.cn/g3603.aspx (accessed May 8, 2018).

(2) Google Earth Pro. Google 2018.

(3) Hydrelio ${ }^{\circledR}$ Floating Solar System | Ciel \&amp; terre https://www.ciel-etterre.net/hydrelio-floating-solar-system-benefits/ (accessed May 15, 2018).

(4) Ciel et Terre International. FLOATING PV SCALES UP: CONSTRUCTION BEGINS ON A 70MWP COMPLEX; 2017.

(5) Ciel et Terre International. Hydrelio ${ }^{\circledR}$ Floating Solar System | Ciel \&amp; terre https://www.ciel-et-terre.net/hydrelio-technology/ (accessed Jul 23, 2018).

(6) WNA. Comparison of Lifecycle Greenhouse Gas Emissions of Various Electricity Generation Sources; London, 2010.

(7) National Energy Administration (NEA) http://en.ndrc.gov.cn/mfod/200812/t20081218_252224.html (accessed May 9, 
2018).

(8) NEA. China's National Energy Administration

http://english.gov.cn/state_council/2014/10/01/content_281474991089761.htm (accessed May 11, 2018).

(9) International Energy Agency. World Energy Outlook 2017: China https://www.iea.org/weo/china/ (accessed May 7, 2018).

(10) Rohde, R. A.; Muller, R. A. Air Pollution in China: Mapping of Concentrations and Sources. PLoS One 2015, 10 (8), e0135749.

(11) Ydersbond, I. M.; Korsnes, M. ScienceDirect Wind Power in China and in the EU: Comparative Analysis of Key Political Drivers. Energy Procedia 2014, 58, 95-102.

(12) Rooij, B. van; Qiaoqiao, Z.; Na, L.; Qiliang, W.; Xuehua, Z. Pollution Law Enforcement in China : Understanding national and regional variation. 2017, 193-207.

(13) Chen, W.; Zheng, R.; Baade, P. D.; Zhang, S.; Zeng, H.; Bray, F.; Jemal, A.; Yu, X. Q.; He, J. Cancer statistics in China, 2015. CA. Cancer J. Clin. 2016, 66 (2), 115-132.

(14) Wong, C.; Karplus, V. J. China's War on Air Pollution: Can Existing Governance Structures Support New Ambitions? China Q. 2017, 231, 662-684.

(15) Liu, L. Made in China: Cancer Villages. Environ. Sci. Policy Sustain. Dev. 2010, 52 (2), $8-21$.

(16) Berkeley Earth. Berkeley Earth http://berkeleyearth.org/china-air-quality-pm2-5/ (accessed May 11, 2018).

(17) Learning from China: A Blueprint for the Future of Coal in Asia? http://www.nbr.org/research/activity.aspx?id=418 (accessed May 13, 2018).

(18) Niu, D.; Song, Z.; Xiao, X. Electric power substitution for coal in China: Status quo and SWOT analysis. Renew. Sustain. Energy Rev. 2017, 70, 610-622. 
(19) Dong, K.-Y.; Sun, R.-J.; Li, H.; Jiang, H.-D. A review of China's energy consumption structure and outlook based on a long-range energy alternatives modeling tool. Pet. Sci. 2017, 14 (1), 214-227.

(20) Finkelman, R. B.; Tian, L. The health impacts of coal use in China. Int. Geol. Rev. 2018, 60 (5-6), 579-589.

(21) Liu, Z.; Guan, D.; Wei, W.; Davis, S. J.; Ciais, P.; Bai, J.; Peng, S.; Zhang, Q.; Hubacek, K.; Marland, G.; et al. Reduced carbon emission estimates from fossil fuel combustion and cement production in China. Nature 2015, 524 (7565), 335-338.

(22) Yang, H.; Huang, X.; Thompson, J. R.; Flower, R. J. Enforcement key to China's environment. Science 2015, 347 (6224), 834-835.

(23) The Economist. How China cut its air pollution - The Economist explains https://www.economist.com/the-economist-explains/2018/01/25/how-china-cut-itsair-pollution (accessed Jul 23, 2018).

(24) Wang, L.; Zhang, F.; Pilot, E.; Yu, J.; Nie, C.; Holdaway, J.; Yang, L.; Li, Y.; Wang, W.; Vardoulakis, S.; et al. Taking Action on Air Pollution Control in the Beijing-TianjinHebei (BTH) Region: Progress, Challenges and Opportunities. Int. J. Environ. Res. Public Health 2018, 15 (2), 306.

(25) Sun, C.; Luo, Y.; Li, J. Urban traffic infrastructure investment and air pollution: Evidence from the 83 cities in China. J. Clean. Prod. 2018, 172, 488-496.

(26) EXCLUSIVE: Dubai plans floating solar power plant | Meed https://www.meed.com/exclusive-dubai-plans-floating-solar-power-plant/ (accessed May 15, 2018).

(27) Ciel et Terre International. Floating Solar Technology documentation | Ciel \&amp; Terre https://www.ciel-et-terre.net/downloads/ (accessed Jul 23, 2018). 
(28) Leuning, R.; Zhang, Y. Q.; Rajaud, A.; Cleugh, H.; Tu, K. A simple surface conductance model to estimate regional evaporation using MODIS leaf area index and the Penman-Monteith equation. Water Resour. Res. 2008, 44 (10).

(29) Shaw, E. M. Hydrology in practice; Spon, 2011.

(30) Floating Solar System - OKEGAWA - 1179,36 kWp https://www.ciel-etterre.net/essential_grid/floating-solar-system-okegawa/ (accessed May 15, 2018).

(31) lightsourcebp. Stories - Lightsource https://www.lightsourcebp.com/uk/stories/qe2/ (accessed May 15, 2018).

(32) Frankfurt School-UNEP Centre/BNEF. 2017. Global Trends in Renewable Energy Investment 2017, http://www.fs-unep-centre.org (Frankfurt am Main).

(33) ABC7. Proposed Floating Solar Farm on Reservoir in Los Angeles http://abc7.com/science/la-councilman-proposes-floating-solar-panels-onreservoirs/3366827/ (accessed May 15, 2018).

(34) Ciel et Terre. Our references: the floating solar expert with hydrelio technology http://www.ciel-et-terre.net/wp-content/uploads/2017/12/CT-ReferencesDecember-2017.pdf (accessed Jul 21, 2018).

(35) The World's First Power Plant To Combine Hydro And Solar Opens In Portugal https://www.huffingtonpost.co.uk/entry/hydro-solarplant_us_595f96dee4b02e9bdb0c0fa6?guccounter=1 (accessed Jul 23, 2018).

(36) Dutch plan to build giant offshore solar power farm | Reuters https://www.reuters.com/article/netherlands-solar-offshore/dutch-plan-to-buildgiant-offshore-solar-power-farm-idUSL8N1Q46M0 (accessed Jul 22, 2018).

(37) Hanwha Q CELLS developing 80MW rotating floating solar project in Korea I PV Tech https://www.pv-tech.org/news/hanwha-q-cells-developing-80mw-rotating-floating- 
solar-project-in-korea (accessed May 15, 2018).

(38) The Difference is in the Detail | LG Solar http://www.lg-solar.com/uk/product/monox-plus.jsp (accessed May 15, 2018).

(39) NASA photo showcases China's Longyangxia Dam Solar Park, world's largest solar farm - People's Daily Online http://en.people.cn/n3/2017/0223/c900009181897.html (accessed May 16, 2018).

(40) Laboratory History | NREL https://www.nrel.gov/about/history.html (accessed May $16,2018)$. 